\title{
Organizational Career Development Practices: Learning from an Omani Company
}

\author{
Sami A Khan ${ }^{1}$, James Rajasekar ${ }^{2} \&$ Ahmed Al-Asfour ${ }^{3}$ \\ ${ }^{1}$ Faculty of Economics \& Administration, King Abdulaziz University, Jeddah, Saudi Arabia \\ ${ }^{2}$ College of Economics \& Political Science, Sultan Qaboos University, Oman \\ ${ }^{3}$ Oglala Lakota College, Kyle, SD, USA \\ Correspondence: Sami A Khan, Faculty of Economics \& Administration, King Abdulaziz University, Jeddah, \\ Saudi Arabia. E-mail: khan.drsami@gmail.com
}

Received: July 6, 2015

doi:10.5539/ijbm.v10n9p88
Accepted: July 22, 2015

Online Published: August 22, 2015

\begin{abstract}
Organizational career development practices have acquired great importance in companies in Gulf Cooperation Council (GCC) countries due to localization of the workforce, and resultant career development initiatives taken by these firms. The present research undertaken in an Omani company attempts to evaluate the career development opportunities being provided to its employees, its efficacy in bringing satisfaction among its employees and expediting the process of Omanization. The study showcases concerns of the employees that have been overlooked by the organization which has a negative impact on their satisfaction. The study suggests involving employees in the career development decision making process, and bringing transparency and fairness in the execution of the career development system can only create a win-win situation. An effective career development process can help in establishing trust between both parties to reach to the desired organizational outcomes.
\end{abstract}

Keywords: career development, career management, employee participation, Oman, human resource management

\section{Introduction}

Career development of employees plays an important role in enriching the human capital component of a company. It is being strategically used to leverage organizational talent, and to attract and retain a competent workforce. Right kind of people management strategy involves sustaining success through building the right kind of organization by using insights on talent, culture and leadership (Ulrich, 2014). Building talent requires an organization to employ the right kind of career development practices in order to provide opportunity for employees to learn and grow. The organizational role in shaping future career opportunities cannot be underestimated. With rapid change, emergence of new technologies, and an increasing rate of knowledge acquisition, it has become important to ensure the benefits of high capacity human capital utilization in organizations (Baruch, 2006). Career development theories began to manifest quite early, but it was not until four decades ago that researchers started to examine the effectiveness of the career development as a HR tool (Richard, 2005), and today, career development is a well-established and widely accepted theme in the contemporary career literature field.

Organizational commitment to employees career development is a concept that has attracted a great deal of attention by many researchers in recent time (Kaur \& Sandhu, 2010). Hence, it is not surprising that much effort has been directed towards studying organizational commitment to employees' career development (Cohen, 2007). Modern organizations need their employees to adapt to constant changes with a minimal amount of disruption, and they turn to constant employee development (Okurame, 2014). In addition, this creates opportunity for employees to grow in their profession and to achieve a distinguished career (Okurame \& Balogun, 2005). Empirical investigations have also shown that organizational career development for employees reinforces optimism in employees to perform their jobs more effectively (Avey, Nimnicht, \& Pigeon, 2010).

Baruch and Peiperl (2000) coined the term organizational career management (OCM). It is concerned with organization carrying out activities relevant to the career development of its employees. This is distinct from 
career management as practiced by individuals, consultants, or job centers. Career management is a commonly cited antecedent of career development process (Ababneh, 2013). Career development has been defined as an on-going and life-long process that involves work-related activities to enhance employee's knowledge on topics related to their work (Hall, 2002; Omair, 2010). Niles and Harris-Bowlsbey (2002) referred to career development as a lifelong psychological and behavioral processes intertwined with contextual influences that shape an employee's career over his or her lifetime. Saviks (2003) viewed career development as an opportunity for employees to plan their lives by reflecting on their abilities, interests, and goals and aligning them with their career paths. Greenhaus, Callanan, and Godshalk (2000) went further by defining career development as an on-going stage characterized by the concerns, themes, and tasks of employee development.

There are many ways to approach employee career development, therefore, managers need to determine the most appropriate and effective approaches (Wexley \& Latham, 2002). Organizations use some common tools, such as self-assessment, individual counseling, succession planning, career ladders, and other activities. When designing a career system, HR managers typically face a plethora of choices. They should incorporate elements based on how these elements are clustered together and how they fit the organizational characteristics (Baruch \& Peiperl, 2000). An effective organizational career management program needs to reflect the organizational realities, and needs to be perceived as appropriate by employees as well. Understanding the elements of an effective development program helps organizations develop their employees and save unnecessary time, efforts, and resources from being used in the wrong direction (Byars \& Leslie, 2011).

\section{Literature Review}

An effective organizational career development program follows a two-pronged approach to meet the strategic need of the firm as well as satisfy the employees by involving them in their career development process. Organizations are interested in developing employees in order to increase their competitive advantage. A good career development program can reduce costs of high employee turnover (Byars \& Leslie, 2011). Responsibility for career management lies both with employees and with the organization that employs them. Career effectiveness will be greater when employee and organization carry out their respective career management roles (Hedge, Borman, \& Bourne, 2006). However, in reality, many organizations implement career development programs without carefully considering the effectiveness of these programs on their employees (Arthur, Bennett, Edens, \& Bell, 2003). Sanjeevkumar (2011) also argued that many career development programs are rarely evaluated in terms of their effectiveness on the behavior or job performance of participants. These programs fail to be effective in transferring learning and knowledge in the workplace. Cromwell and Kolb (2004) found that only $15 \%$ of the career development programs adopted in organizations were effective in transferring knowledge of the participants to their jobs. Thus, there is a strong need to review the career development programs adopted by organizations to learn about their effectiveness (Pelham, 2009) and efficacy in terms of changing the work environment. An effective career development program forms part of a coherent HR strategy, where institutionalizing a career development culture engages employees as well as realizes organizational goals. A well-managed career development culture can offer great rewards to an organization and people working in it (Conger, 2002).

Careers in organizations have undergone a transformation to meet the demand of fast changing business environments. Job security has become a non-existent in many organizations and many firms emphasize developing employability of employees as a people management strategy. Baruch (2004a) also found that employers have moved away from providing secure employment for all to providing opportunities for employees' development. An effective career development program is an important predictor of how well employees learn and use knowledge and competency at the workplace. Many researchers have identified that an effective employee development program helps retain employees and build their morale (Ababneh, 2013; DelaCruz, 2004) Good HR policies need to address these concerns to better serve the strategic purposes of the organization. Conger (2002) emphasized that the cost benefit analysis of a career development initiative can better leverage a program in a firm. Sanjeevkumar (2011) suggested that effective career planning for employees requires their participation in setting their own goals, which ensures their learning and growth. Baruch and Peiperl (2000) suggested types of organizational career management practices depending upon the degree of involvement of employees and degree of sophistication of these practices. Researchers in the career management field have not yet found a science-based guide to make accurate decisions regarding the types of techniques (Wexley \& Latham, 2002) that are the most successful to use. Therefore, organizations must design career development programs based on their needs as well as the competencies and aspirations of their employees.

Flexible career management is the opposite of psychological contract that dominated in 1980s and 1990s (Markaki, Sakas, \& Chadjipantelis, 2013). In the past, development of employees used to be seen as the sole 
responsibility of the employer but this is not relevant today. Now, individual employees are equally responsible in deciding their career paths and developing their employability due to the fact that linear career growth paths in firms are less visible. Developing employability of employees by providing more opportunities for their learning and growth has become highly relevant. Employability encompasses acquisition of skills, understanding, and abilities that employers value, and broadly recognized as contributing to an employee's career potential (Erford \& Crockett, 2012). Lent (2013) prescribed career preparedness of employees to deal with the possible barriers by bolstering their beliefs about their ability to cope with setback, surprises, and transition, and by proactively building supports and coping resources. He also recommended proactive strategies to manage one's own career to better deal with career challenges of today (see also, Savickas, 2011). Lysova, Richardson, Khapova, and Jansen (2015) argued that 'career identity' is important, as it guides our career development and influences our perceptions of our work, our behavior in the workplace, and a proactive career behavior. A focus on other-oriented work values results in higher levels of employee engagement as well.

There is a growing debate among scholars and HR practitioners on the need of organizations to refocus on the career development approach towards its employees (Clarke, 2005; Lohman, 2005). A question of who is in charge arises when examining employee career development. Baruch (2006) indicated that there are two extreme views on who is in charge of career development. One extreme view is that organizations are in charge, since they develop a strategic plan, which in most cases, includes a career development element for employees. The other extreme view is that employees should be responsible, as they should be in charge of their own destiny. In that context, researchers found that the landscape of career development has been vigorously changing for both employers and employees and that there is a need for a balanced approach (Baruch, 2006; Mayrhofer, Meyer, Iellatchitch, \& Schiffinger, 2004; Peiperl \& Baruch, 1997). Baruch (2004b) developed a career development model entitled Career Active System Triad (CAST) after reconciling the interests and concerns of both parties. In this model, Baruch attempted to create a balance between employees and their organizations, emphasizing different aspects of a successful career development in which each needs to focus. Furthermore, he advocated that organizations need to move away from traditional approach of employee career development through the command and control approach to an approach showing support for employee career development (Baruch, 2006).

Career development is seen as a structured approach used to help employees fulfill certain requirements of various positions within the organization throughout their career lifespan, considering organizational needs and requirements. The purpose of career development is to enrich employees' skills and knowledge in order to make them fit for future positions and emergent roles and responsibilities. Individual career development should emphasize the role of employees in honing their skills (Greenhaus et al., 2000). Cooper (2005) added that employees need to have a proactive behavior to attain the qualities essential for their career success, and they should steer the direction of their future. This, however, does not mean that organizations should underestimate their own contribution to employees' career development. Employers should develop a framework for employees career development through psychological contract with their employees (Moreley, 2004). This psychological contract should be a mutual agreement between both parties regarding organizational and employees' short and long-term development (Mayrhofer et al., 2004; Cooper, 2005).

The rapid changes in technologies and human capital knowledge acquisition encourage employers to emphasize the need for a continuous career development. Training and development of employees play an instrumental role in maintaining both employee satisfaction and performance by using career development (DelaCruz, 2004). By having well-developed employees, organizations will have the human capital to achieve their objectives (Lalao, Alariss, \& Isabelle, 2012). Kulkarni (2013) suggested that employee development programs should include attention to employee education, employee skill development, training effectiveness criteria, and employee quality of work life. Because employee development is an essential part of organizational success, it is imperative for employers to find the best and most effective method to develop their employees' skill (Devins, Johnson, \& Sutherland, 2004). Methods needed to develop employees involve on-the-job and off-the-job learning. On-the-job learning could include job instructions, apprenticeship, coaching and mentoring, job rotation, job enrichment or job enlargement, opportunities to apply learned skills, and committee assignments (Burke \& Hutchins, 2008; Kulkarni, 2013). On the other hand, off-the-job learning could include simulation exercises, classroom lectures, such as courses at educational institutions, seminars, and conferences (Byars \& Leslie, 2011; Wexley \& Latham, 2002). Many organizations use on-the-job learning to train new employees (Khan, Nawab, \& Wali, 2012). On-the-job training offers new employees an opportunity to interact with senior colleagues and learn first-hand organizational knowledge (Kowtha, 2011). Zeytinoglu, Cooke, Harry, and Chowhan (2008) found that low paid workers are more likely to go through on-the-job training, as their skills 
need to be developed within their workplace. Off-the-job training is a common approach that organizations use to enhance employees' skills that are not supported at employee's workplace. This usually applies more to individuals who hold higher positions within organizations (Zeytinoglu et al., 2008).

It has been found that most dominant theoretical and empirical work in career development has been done in "the West" and shaped by North American and Western European influences. Despite that, these studies have relevance for other parts of the world (Healy \& Ozbilgin, 2003), and developing human capital and career development of employees has become a part of development policy in many developed and developing countries (Watts \& Fretwell, 2004). Seeing the onslaught of economic slowdown, globalization, and consequent downsizing, the notion of job security has become outdated. There is a strong need for an integrated HR strategy that would take into account a balanced career development strategy in line with overall HR strategy. To realize the organizational goals better, talent management and development of employees should involve proactive engagement of employees, showing to all stakeholders that the company cares about its employees. Talent management has taken the center stage in the management of people in the organization these days, and it has also become highly relevant for the organizations based in the Middle Eastern countries, especially in GCC (Gulf Cooperation Council) countries. Saudization, Emiratization, Qatarization, Omanization etc. are widely used terms to showcase the necessity of localization of the workforce in these countries and the success of GCC organizations in retaining talent and filling organizational positions from the internal supply of the workforce (see also, Al-Asfour \& Khan, 2014; Rajasekar \& Khan, 2013; Budhwar \& Mellahi, 2007). Based on this background, the present case is an attempt to understand the dynamics of organizational career development practices adopted in an Omani firm.

\section{Research Methodology}

This is a case study of a petroleum product company, which was established in late 1990s and is seen as a model employer in the Sultanate. The identity of the organization is not revealed to maintain the confidentiality of the data, and a pseudo name, Oman Natural Gas (ONG) is used in this case study. The data was collected during the years 2013-2014. A multipronged approach was used to collect the data. Focus group discussions were conducted with employees in various departments and supervisor/line managers separately. Unstructured interviews with HR and training managers were conducted separately. Unstructured interviews covered open-ended questions on the career development programs adopted in ONG, its efficacy, challenges and problems being faced in implementing these programs, perception of line managers and employees, involvement of employees, and linkages of career development program with other HR interventions adopted at ONG, e.g., training and development, performance appraisal, reward management, change management program. To reinforce our findings, we distributed questionnaires to 75 employees representing various departments of the chosen Omani firm $(\mathrm{N}=476)$ with 63 completed questionnaire being returned. All respondents were male Omani of an average age of 31.7 years. The questionnaire was first developed in English language, and was translated in Arabic for better appreciation and understanding of the questions asked. It was comprised of 20 items assessing basic demographic profile like age, education, gender, years of experience, length of services at ONG, job grades etc., and questions on career development practices offered at ONG. The questions covered were carefully framed to gather information on the types of career development programs being offered at the firm; the career programs that the respondents had completed. Their views on the efficacy of these programs; the importance of career development from their viewpoints; the clarity and employees awareness of their own career development plans. Their views on their preferred career development program, and the satisfaction level of employees with the career development programs and career development decision making process. The research has its limitation, as it is based on the sample of a single Omani company pursuing the career development strategy for its employees.

\section{Company Profile}

The chosen company, ONG, is a limited liability incorporated joint venture company established by Royal Decree. The construction work started in November 1996, and the plant was commissioned in September 2000. The main shareholder is the Omani Government with 51\% share, whereas other private partners own $49 \%$ of the share. In 2013, the revenue of the company was US\$ 4,342 million, which is US\$ 379 million more than in 2012. The company achieved a net income of US\$ 1,950 million after taxes in 2012, which was an increase of US\$ 168 million from the year 2012. The company produces and sells liquefied natural gas and a byproduct, natural gas liquids. The company undertakes, directly or indirectly, project operations and activities necessary to liquefy, store, transport, and market natural gas. The company's head office is located in Muscat, Oman. The company emphasizes the development of business and of its employees, as well as to their potential and is considered as a trusted partner in the sustainable development of Oman and its people. The company had 476 
employees by the end of the year 2013, and 421 of them were Omanis, making $89.8 \%$ Omanization level for which the company was given recognition by the Ministry of Labour, Sultanate of Oman. The company's HR policy claims to apply the company values of respect, care, fairness, and transparency when attracting, developing, and motivating its employees. It aims to recruit employees based on merit in compliance with job requirement goals, eschew prejudice and discrimination, and it strives to instill a learning culture in all employees and teams. As a part of its HR policy, the company aims to invest in developing employees to their fullest potential within the company based on performance, and ability in accordance with the company goal of being an equal opportunity provider. The company claims to provide well-defined development opportunities to its employees based on potential career paths backed by professional training, coaching, and mentoring. The company considers its ability to attract, develop, and retain Omani talent as a key factor for its success. In 2013, it invested over US\$ 4.8 million in the training and development of employees who now occupy most of the senior roles in the company.

\section{Findings}

It was quite surprising to find a huge gap between the perception of employees of the existing career development program and that of their supervisors/line managers and HR managers. Most organizations, including ONG, grapple with providing a balance in their employee development programs. Career development and planning needs should be balanced so that future vacancies can take advantage of talent inside the firm. Career development must add value to the organizational resources of the firm and form a substantial part of HR strategy and talent management initiative. The current career development schemes put greater emphasis on the senior and critical positions. This is understandable because those who occupy critical positions need to be groomed and developed properly to improve the management of the business. These positions carry higher responsibilities and hence require learning and development to reach the desired competence level. Managers reported that the lower positions have career development and progression programs but they are not as clear as are those adopted for the senior positions, causing a moral problem for those having lower positions. Nevertheless, the organization is currently reviewing its career development scheme, which may improve and remove the current ambiguities that the employees face.

At present, ONG is using following career development practices to develop the career of its employees:

- Short training courses: These usually last few days up to few weeks. The idea behind these courses is to enhance employees' knowledge and refresh their mind on certain work aspects. They are usually a mixture of in-house courses, external courses being conducted locally, regional courses conducted in the GCC countries, and courses being conducted abroad (other than the GCC).

- Cross-functional training: This type of training is usually done across departments within the organization. For instance, employees from the marketing department (back office support) who usually deal with the finance team for payment processing purposes (e.g., invoicing, interest charge), are assigned to a few weeks' training (depending on the requirement) in the finance department to gain knowledge of the invoicing system, the flow of payments, interest charge calculations, and so on. This helps marketing employees respond to any of their customers' financial queries without having any unnecessary interruption. Another example is that employees from internal audit department are assigned to certain departments to get an overview of their areas of business as well as their roles and responsibilities. This increases their understanding before conducting an audit. The same is applicable to various departments at ONG. This type of training leads to a better understanding of roles and responsibilities across functions. Hence, results in better and stronger relationships.

- Short-term assignments: At ONG, these assignments last usually few months, and they are offered in conjunction with shareholders' companies for the purpose of sharing knowledge as well as enhancing their knowledge of other businesses. In addition, these are also being done within the company where employees are assigned to work on different short term projects with the objective of diversifying their skills and knowledge in the new areas of business. Usually, when a new organizational project gets into place, an employee is selected from each department to act as a focal point for his or her department and liaise with the concerned project to provide all information needed.

- Long-term assignments (cross-posting): These assignments carry longer tenure, i.e., 3-4 years long. At ONG, the purpose of these types of assignments is to develop the employees through holding a new position in a new area of business and working with new teams and environment in order to be able to hold a senior position, provided a vacancy is available.

- On the Job training: These training offers opportunities for employees to get hands-on experience in certain areas related to their job. For example, an employee from HR department's recruitment section whose plan is to 
have some knowledge in the training and development area is assigned to a few months on-the-job training program in the training and development field. Similarly, technical staffs are sent to other technical fields to improve and widen their technical skills in certain areas.

- Professional Certification: These opportunities are sponsored by the organization for employees to pursue professional certifications in their field of work in order to qualify themselves for higher positions. ONG gives due credit to accredited certification while moving people up the career ladder.

ONG has shown considerable amount of commitment to providing its employees with opportunities to develop their skills and enhance their knowledge. Most employees are assigned to short training courses followed by on-the-job trainings. The least being assigned to employees is the cross-posting program, which involves long-term assignment. Competition among the employees to obtain temporary positions in another organization for a period of around 3-4 years (i.e., cross-posting assignment) is huge. Furthermore, sending employees abroad to fulfill these cross-posting assignments is also costly, and it includes accommodation and family education allowances, just to name a few. Despite the fact that a large number of employees are being sent to short-term training courses, the effectiveness of these programs needs to be evaluated at ONG.

Nearly three-fourth of respondents $(74.6 \%)$ believe that on the job training (OJT) is the most effective career development method at ONG, providing them with hands on experience and an opportunity to learn, act, and remove ambiguities if any exists. Other respondents also supported short assignments, as they can provide a great opportunity for them to experience working with new staff, in new environment, with new teams, and with new tasks. Very few employees selected cross posting (long-term assignments) as an effective program, but those who selected these assignments felt that they add immense value to the assigned employees by letting them experience a new work culture as well as a new living experience, depending on the country to which the employee is sent. Unfortunately, due to the high costs involved, the firm is only able to accommodate a limited number of staff requests for such programs at ONG. Some employees commented that the assignment to career development programs depends on the discipline of the employee as well as his or her job and responsibilities. Van der Klink and Streumer (2002) argued that OJT helps establish a favorable relationship between training costs and its benefits. This view was reinforced in this study; thus, employees felt more motivated to participate in the OJT rather than other training courses.

Markaki et al. (2013) found that career management and communication management are highly interrelated and, if done properly, it can lead to organizational success. It was found in this case study that more than half (55.5\%) of the respondents said that they were involved in career development programs at some time whereas $12 \%$ respondents said that they were always involved. However, nearly one-third of the respondents have never been involved in their career development decision, which is worrisome and indicates lack of involvement of employees in designing career development program. Employees were asked about the parties involved in the selection of their career development plans and about their views on who should ideally be involved in the selection process. It was found that employees, along with their line managers, are currently involved in this process and training and development staffs are some time also involved in making such decision. There is a need to design a structured communication process, and employees feel that all three parties need to be involved in a career development process. Involving employees, who are at the focus, followed by the line manager and then finally involving the training and development staff members who offer advice and support, will make the program more effective.

It was observed that at $\mathrm{ONG}$, an extremely high percentage of employees were not satisfied with the present career development plans and they found lack of transparency and clarity in their career development plans and career paths. Only $4.7 \%$ of the respondents reported higher level of satisfaction from the career development program, whereas $49 \%$ indicated an average satisfaction level, and $46 \%$ reported low level of satisfaction with the career development program. Employees felt that even if a career development plan was in place, it was not followed properly and the program was changed unexpectedly without informing them. Employees are sent to a particular training course if their line managers see it as important, and employee's consent is not taken seriously. Employees indicated their unhappiness with the support as well along with a lack of appreciation from their supervisors. According to Morrison's model, recognition involves acknowledgement and rewards for achievement in the form of promotions, pay increases, and awards, and support involves acceptance and understanding by the organization (Burke, 1995). Employees who reported the existence of a clear career development plan mentioned that it is somewhat difficult to achieve. Plan often requires, for instance, a professional certification to move from position A to B. Impediments in obtaining certifications are the long working hours required and the commitment that is required from the family. These were also some of the reasons why employees criticized the organization's lack of commitment to provide a work-life balance. 
Employees believe that the organization should consider work-life balance to allow for flexibility and multiple options for career progression and development.

Lack of knowledge or skill is only one of the possible factors hindering the job performance. Other factors are equally important. Lack of tools or equipment, unclear job expectations, no supportive supervision, no feedback on job performance, no feedback on change adopted, inadequate motivation, lack of incentives and others are some factors retarding performance. Therefore, training alone may not be the solution (Hannum, 2009). Having asked the employees about their views on the key reasons for employee's underperformance, most respondents at ONG chose 'unclear career path' (53.9\%) and 'unclear job expectations' (46\%) as the most important reasons while lack of training was rated the lowest (7.9\%), and only $12.7 \%$ reported lack of incentives and reward as the reason for non-performance. This clearly reflects the above-mentioned myth, and now purported fact, that lack of training is not necessarily the key reason for the underperformance and training is not the only answer or solution to high performance. In fact, high performance is a culmination of employee engagement and empowerment as well as the creation of a performance oriented work environment with right kind of reinforcement and reward strategy. At ONG, the responses of employees indicated that they underperform if there is lack of clarity (e.g., in job description, job expectations, gap in psychological contract, lack of feedback process, and poor career path) in the work environment. Employees value transparency and need to get involved as well. It is extremely important to have transparency within any work environment as a critical factor to prevent employees from being demotivated and underperforming, and it can be achieved by engaging them in the decision making process.

It was observed that to make a career development program effective, skill enhancement of employees must be done properly. Training intervention at ONG was not able to achieve its desired goals despite huge funds being spent on it. There is a greater need to have a training evaluation system in place at ONG to validate the utility and usefulness of the training. An analysis of employees' feedback on the current training evaluation system revealed that most employees found the training evaluation system to be poor. The current evaluation system at ONG is electronic, and it is mandatory for employees to respond to it after the completion of training. The online questions assess three components of the training regarding the instructor, the course, and the environment. Employees found that the system is not effective and does not provide enough space for them to express their views freely. It lacks open-ended questions where employees can express their views in their words. Employees' perceptions are also not well received and not given much importance by their managers.

Recently, ONG has proposed to redesign its career development schemes to improve its efficacy. The company has collected the employee's opinion and proposed a new scheme called 'graduates scheme' for fresh hired graduates to offer a very clear structured plan consisting of various stages of career development with specific requirements. The organization is currently seeking to standardize all similar job titles among different departments to eliminate unnecessary discrepancies. For instance, all graduates would be having similar job titles and at the next level up they would be called analysts, and so on. Another innovative approach of the new career development plan is that vacancies are no more seen as an obstacle. A new plan has been introduced for those who are secondary and diploma holders as well. The purpose of this plan is to give both groups the opportunity to move up the career ladder to the next salary group level even without having the vacancy. Hence, at each stage, they would have certain specified requirements that would need to be fulfilled to be eligible for promotion. In other words, bachelor's degree holders will enjoy this flexibility in moving from level SG7 to SG6 to SG5. Thereafter, their career path will depend upon existence of a vacant position and employee's promotability. The same principle applies for the secondary and diploma holders to move from level SG13 to SG12 to SG11 and so on up to the level SG8. Thereafter, the career path depends upon the vacant position and employee's promotability.

The new career development scheme plan adopts a competence matrix for each job, which provides a blueprint for career path in a given department and the required competencies to fulfil these jobs. Competencies included are not only specific to the relative department, but also to other functional areas. The competency levels are divided into following four areas:

- Awareness (A): Basic awareness is described in basic terms with specific list of items.

- Knowledge (K): Beyond awareness, knowledge can help explain and lead to an informed debate involving the items listed on the specified list.

- $\quad$ Skill ( $\mathrm{S})=$ Beyond knowledge, one can do the tasks listed in the specified list.

- $\quad$ Mastery $(M)=$ Skill Plus, one can do the tasks that are specified in the list. 
The new proposed career development plan is being prepared for its implementation, and there is a great hope that it will contribute to the organization effectiveness and improve the employee satisfaction as well. The employee engagement and involvement will still reflect the efficacy of the new system. The organization is also willing to provide a clearer career path for their employees. In recent time, the organization has encouraged its employees to express their views on career development plans through an online survey. The survey data are yet to be analyzed, but it is evident that a dialogue has been initiated with employees who are getting involved. The proposed arrangement seems to adopt a more structured career planning technique, but its implementation and outcome need to be analyzed to determine whether the organization is able to engage its employee proactively in their career development programs or not.

\section{Conclusion}

The existing career development plan at ONG has not been able to involve and enthuse the employees. Comparison of both employees as well as the organization's views revealed that there is a gap in the way career development plans are being perceived and implemented so far. Employees are mostly unhappy with the present career development system and find absence of clarity and transparency in its implementation. There was a gap between the employees and their managers in their perceptions of the career development. Employees' views were quite different from those of their managers. Employees indicated that the present career development program adopted in the organization is poor. Managers need to better communicate and involve employees in adopting these career development plans. This is one of the important reasons why employees get demotivated when they are assigned to programs, which they do not find relevant and useful. Their opinions are not considered and they lack ownership of these programs, resulting in its poor perception and effectiveness at ONG.

Overall, ONG is facing a challenge and striving hard to provide an attractive development opportunity for its employees. Very recently, it has proposed a new career development plan and has collected employees' views through online surveys with an aim to anticipate and manage their career plans better. Competency mapping is being proposed for each job, and employees are being approached to air their views. It is expected that employee's level of awareness would increase once the new plan is in place. However, it is very crucial for employees to have a feeling of transparency and fairness in its execution. There is a strong need to involve the employees more vigorously in the improvement of the career development system, which requires using more vigorous data collection methods in addition to the survey. The company must involve employees in making career development decision to create a win-win situation. It was observed that employees prefer short assignments and on the job training programs in comparison to the short-term training courses. Hence, organization must look into these methods before offering any training. ONG must use mentoring and coaching programs as a tool to reinforce career development programs. These tools can be of great help in inculcating right values among the employees and making them more engaged and involved.

Careers in organizations have undergone a transformation in the present business environment, and job security is becoming outdated. The development of employability of the employees needs to be emphasized as a strategic people management strategy. Firms should adopt comprehensive deployment and development strategies with the objective of a career and talent management initiative to be realized in the larger HR policy framework. An effective career development program is an important predictor of how well employees learn and use knowledge and competence in the workplace. Overall, leadership becomes highly relevant for making any such program more pervasive. Top managers and line managers should show commitment to career development program, regularly disseminate information, and communicate with the employees to attract more attention to the desired program. HR department has to play a strategic role in coordinating these efforts and involving line managers in the employee development process. Developing a talented and committed workforce will not only pave the way for Omanization in the Omani firms, but it will also encourage them to undertake the important roles within the organization by replacing the expatriate workforce when necessary.

\section{Limitations and Future Research Directions}

The research has its own limitation, as it is a case study of career development practices adopted in a single Omani company, and there is a greater likelihood that all aspects of career development programs are not being covered in this research. The company has just started the process of revising its career development program which is more aimed towards developing the talent of Omani employees. A further research on the effectiveness of the proposed program can be undertaken after some time to assess the efficacy of career development practices in developing employees, increasing their morale and satisfaction level, and making the firm more strategically congruent to serve the larger organizational outcomes. 


\section{References}

Ababneh, R. (2013). Antecedents and outcomes of career development in Jordanian public sector. Journal of Emerging Trends in Economics and Management Sciences, 4(1), 417-426.

Al-Asfour, A., \& Khan, S. A. (2014). Workforce localization in the Kingdom of Saudi Arabia: Issues and challenges. Human Resource Development International, 17(2), 243-253. http://dx.doi.org/10.1080/13678868.2013.836783

Arthur, W., Bennett, W., Edens, P. S., \& Bell, S. T. (2003). Effectiveness of training in organization: A meta-analysis of design and evaluation features. Journal of Applied Psychology, 88(2), 234-245.

Avey, J. B., Nimnicht, J. L., \& Pigeon, N. G. (2010). Two field studies examining the association between positive psychological capital and employee performance. Leadership and Organizational Development Journal, 31(5), 384-401. http://dx.doi.org/10.1108/01437731011056425

Baruch, Y. (2004a). Managing careers: Theory and Practice. Harlow, UK: FT-Prentice Hall/Pearson Education.

Baruch, Y. (2004b). Transforming careers: From linear to multidirectional career path. Career Development International, 9(1), 58-73. http://dx.doi.org/10.1016/j.hrmr.2006.03.002

Baruch, Y. (2006). Career development in organizations and beyond: Balancing traditional and contemporary viewpoints. Human Resource Management Review, 16(2), 125-138. http://dx.doi.org/10.1016/j.hrmr.2006.03.002

Baruch, Y., \& Peiperl, M. (2000). Career management practices: An empirical survey and implications. Human Resource Management, 39(4), 347-366. http://dx.doi.org/10.1002/1099-050x (200024)

Budhwar, P., \& Mellahi, K. (2007). Introduction: Human resource management in the Middle East. The International Journal of Human Resource Management, 18(1), 2-10. http://dx.doi.org/10.1080/09585190601068227

Burke, L. A., \& Hutchins, H. M. (2008). A study of best practices in training transfer and proposed model of transfer. Human Resource Development Quarterly, 19(2), 107-128. http://dx.doi.org/10.1002/hrdq.1230

Burke, R. J. (1995). Career development in a professional services firm on-the-job experiences and continuous learning. The Journal of Management Development, 14(1), 25-33. http://dx.doi.org/10.1108/02621719510075879

Byars, L. L., \& Leslie, W. R. (2011). Human resource management (10th ed.). New York, NY: McGraw-Hill.

Clarke, N. (2005). Workplace learning environment and its relationship with learning outcomes in healthcare organizations. Human Resource Development International, 8(2), 185-205. http://dx.doi.org/10.1108/02621719510075879

Cohen, A. (2007). Commitment before and after: An evaluation and reconceptualization of organizational commitment. Human Resource Management Review, 17, 336-354. http://dx.doi.org/10.1016/j.hrmr.2007.05.001

Conger, S. (2002). Fostering a career development culture: Reflections on the roles of managers, employees and $\begin{array}{lllll}\text { supervisors. } & \text { Career } & \text { Development } & \text { International, } & 7(6),\end{array}$ http://dx.doi.org/10.1108/13620430210444394

Cooper, C. L. (2005). The future of work: Careers, stress and well-being. Career Development International, 10(5), 396-399. http://dx.doi.org/10.1108/13620430510615319

Cromwell, S. E., \& Kolb, J. A. (2004). An examination of work-environment support factors affecting transfer of supervisory skills training to the workplace. Human Resource Development Quarterly, 15(4), 449-471. http://dx.doi.org/10.1002/hrdq.15

DelaCruz, T. (2004). Effective training helps retain employees, build morale. Hotel and Motel Management, 219(5), 11-13.

Devins, D., Johnson, S., \& Sutherland, J. (2004). Employer characteristics and employee training in UK SMEs: A multivariate analysis. Journal of Small Business and Enterprise Development, 11(4), 449-457. http://dx.doi.org/10.1108/14626000410567099

Erford, B. T., \& Crockett, S. A. (2012). Practice and research in career counseling and development-2011. The Career Development Quarterly, 60(4), 290-332. http://dx.doi.org/10.1002/j.2161-0045.2012.00024.x 
Greenhaus, J. H., Callanan, G.. A., \& Godshalk, V. M. (2000). Career management (3rd ed.). Fort Worth, TX: Dryden Press.

Hall, D. T. (2002). Careers in and out of organization. Thousand Oaks, CA: Sage Publication.

Hannum, W. (2009). Training myths: False beliefs that limit the efficiency and effectiveness of training solutions, part 1. Performance Improvement, 48(2), 26-30. http://dx.doi.org/10.1002/pfi.20051

Healy, G., \& Ozbilgin, M. (2003). Same bed different dreams: Career development in Middle East. Career Development International, 8(2), 49-51. http://dx.doi.org/10.1108/cdi.2003.13708baa.001

Hedge, J. W., Borman, W. C., \& Bourne, M. J. (2006). Designing a system for career development and advancement in the U.S. Navy. Human Resource Management Review, 16(3), 340-355. http://dx.doi.org/10.1016/j.hrmr.2006.06.002

Kaur, K., \& Sandhu, H. S. (2010). Career stage effect on organizational commitment: Empirical evidence from Indian banking industry. International Journal of Business and Management, 5(12), 141-152. Retrieved from http://www.ccsenet.org/journal/index.php/ijbm/article/view/8499/6340

Khan, I., Nawab, S., \& Wali, S. S. (2012). Influence of employer's provided on-the-job training on employees, wage growth and job performance: An empirical evidence of telecommunication industry of Pakistan. Academic Research International, 3(2), 579-588. Retrieved from http://www.savap.org.pk/journals/ARInt./Vol.3(2)/2012(3.2-73).pdf

Kowtha, N. R. (2011). School-to-work transition and newcomer socialization: The role of job-related education. Journal of Management and Organization, 17(6), 747-763. http://dx.doi.org/10.1017/S1833367200001152

Kulkarni, P. (2013). A literature review on training and development and quality of work life. Journal of Arts, Science and Commerce, 4(2), 136-137.

Lalao, K. R., Alariss, A., \& Isabelle, B. (2012). Careers of skilled migrants: Understanding the experiences of Malagasy physicians in France. Journal of Management Development, 31(2), 116-129. http://dx.doi.org/10.1108/02621711211199467

Lent, R. W. (2013). Career-life preparedness: Revisiting career planning and adjustment in the new workplace. The Career Development Quarterly, 61(2), 2-14. http://dx.doi.org/10.1002/j.2161-0045.2013.00031.x

Lohman, M. C. (2005). A survey of factors influencing the engagement of two professional groups in informal workplace learning activities. Human Resource Development Quarterly, 16(4), 501-527. http://dx.doi.org/10.1002/hrdq.1153

Lysova, E. I., Richardson, J., Khapova, S. N., \& Jansen, P. G. W. (2015). Change supportive employee behavior: A career identity explanation. Career Development International, 20(1), 38-62. http://dx.doi.org/10.1108/CDI-03-2014-0042

Markaki, E. N., Sakas, D. P., \& Chadjipantelis, T. (2013). Communication management in business: The latent power for career development. Procedia-Social and Behavioral Sciences, 73, 319-326. http://dx.doi.org/10.1016/j.sbspro.2013.02.058

Mayrhofer, W., Meyer, M., Iellatchitch, A., \& Schiffinger, M. (2004). Careers and human resource management-a European perspective. Human Resource Management Review, 14(4), 473-498. http://dx.doi.org/10.1016/j.hrmr.2004.10.006

Moreley, M, J. (2004). Contemporary debates in European human resource management: Context and content. Human Resource Management Review, 14(4), 353-384. http://dx.doi.org/10.1016/j.hrmr.2004.10.005

Niles, S. G., \& Harris-Bowlsbey, J. (2002). Career development interventions in the 21st century. Upper Saddle River, NJ: Merril Prentice Hall.

Okurame, D. E. (2014). Individual factors influencing career growth prospects in contexts of radical organizational changes. International Business Research, 7(10), 74-87. Retrieved from http://www.ccsenet.org/journal/index.php/ibr/article/view/40634

Okurame, D. E., \& Balogun, S. K. (2005). Role of informal mentoring in the career success of first-line bank managers: A Nigerian case study, Career Development International, 16(6/7), 512-521. http://dox.doi.org/10.1108/13620430510620584

Omair, K. (2010). Typology of career development of Arab women managers in the United Arab Emirates. Career Development International, 15(2), 121-143. http://dx.doi.org/10.1108/13620431011040932 
Peiperl, M. A., \& Baruch, Y. (1997). Back to square zero: The post-corporate career. Organizational Dynamics, 25(4), 7-22.

Pelham, A. (2009). The impact industry and training influences on sales force consulting time and consulting effectiveness. Journal of Business and Industrial Marketing, 24(8), 574-584. http://dx.doi.org/10.1108/08858620910999448

Rajasekar, J., \& Khan, S. A. (2013). Training and development function in Omani public sector organizations: A critical evaluation. Journal of Applied Business and Economics, 14(2), 37-52.

Richard, G. V. (2005). International best practices in career development: Review of the literature. International Journal for Educational and Vocational Guidance, 5(2), 189-201.

Sanjeevkumar, V. (2011). A study on training factors and its impact on training effectiveness in Kedah state development corporation Kedah Malaysia. International Journal of Human Resource Studies, 1(2), 136-156. http://dx.doi.org/10.5296/ijhrs.v1i2.1130

Savickas, M. L. (2011). Constructing careers: Actor, agent, and author. Journal of Employment Counseling, 48(4), 179-181. http://dx.doi.org /10.1002/j.2161-1920.2011.tb01109.x

Saviks, M. L. (2003). Advancing the career counseling profession: Objectives and strategies for the next decade. The Career Development Quarterly, 52(1), 87-96. http://dx.doi.org/10.1002/j.2161-0045.2003.tb00631.x

Ulrich, D. (2014). The future targets or outcomes of HR work: Individuals, organizations and leadership. Human Resource Development International, 17(1), 1-9. http://dx.doi.org/10.1080/13678868.2013.825144

Van der Klink, M. R., \& Streumer, J. N. (2002). Effectiveness of on-the-job training. Journal of European Industrial Training, 26(2/3/4), 196-199. http://dx.doi.org/10.1108/03090590210422076

Watts, A. G., \& Fretwell, D. H. (2004). Public policies for career development: Case studies and emerging issues for designing career information and guidance systems in developing and transition economies. Washington, DC: World Bank. Retrieved http://siteresources.worldbank.org/EDUCATION/Resources/278200-1126210664195/1636971-1126210694 253/Case_Studies_Emerging_Issues.pdf

Wexley, K. N., \& Latham, G. P. (2002). Developing and training human resources in organization (3rd ed.). Upper Saddle River, NJ: Pearson Education.

Zeytinoglu, I. U., Cooke, G. B., Harry, K., \& Chowhan, J. (2008). Low-paid workers and on-the-job training in Canada. Relations Industrielles, 63(1), 5-29. http://dx.doi.org/ 10.7202/018120ar

\section{Copyrights}

Copyright for this article is retained by the author(s), with first publication rights granted to the journal.

This is an open-access article distributed under the terms and conditions of the Creative Commons Attribution license (http://creativecommons.org/licenses/by/3.0/). 